As we report on page 156, Germany aims by mid-century to produce at least $80 \%$ of its electricity, and more than half of the energy it needs for heating, from renewable energy sources such as sunlight and wind. Thousands of scientists and engineers are developing the power-storage and transmission technologies required to accommodate tomorrow's fluctuating energy sources. The task is enormous. Nevertheless, given the growth rate of renewable energies in recent years - and the high level of public acceptance of the policy - the goals could be achieved even earlier than planned.

In the public's perception, the Energiewende has less to do with global warming than it has with the nuclear disaster at Fukushima in Japan two years ago, which accelerated the proposed phase-out of nuclear power in Germany. In fact, the closure of eight nuclear power plants has made Germany - at least temporarily - more dependent on coal, which will make near-term reduction targets for greenhousegas emissions harder to achieve.

The German effort is no less impressive for all that. Merkel and the German public are displaying admirable courage in turning the country into a laboratory for energy policies (and technologies) which could become models for many industrialized countries. That the nation is running this costly and risky self-experiment against the background of a European arch financial crisis should stand as an enduring testament to Merkel's leadership.

Germany, with its population of some 80 million, is an ideal test ground. The country can afford the Energiewende - which some commentators estimate will cost more than $€ 1$ trillion (US $\$ 1.3$ trillion) because its economy is doing well. And the country is large and diverse enough - economically, geographically and socially - to make the outcome of the great experiment relevant to the rest of the world.

If German's transition to cleaner energy succeeds, then the country will have learned scientific, technical and economic lessons that it will take to the market place and that will solidify its leadership in green technologies. Countries that might eye the German plans with some scepticism now could eventually build on these technologies when they start to reshape their own energy systems.

If the Energiewende founders, however, it will send out a very negative

"Merkel and the German public are displaying admirable courage in turning the country into a laboratory for energy policies." message. Sceptics worldwide will argue that if Germany can't make it work, then nobody can. It is crucial, therefore, that Germany maintains its chosen path through whatever storms may come and even if moans about high electricity prices become more audible.

Ultimately, any truly green economy must include all economic sectors. The Energiewende will not be complete without a new approach to transport. It took generous incentives to convince millions of German homeowners to invest in expensive (and aesthetically debatable) rooftop solar panels. Convincing Germans - or any other nation - to switch to battery-driven or electric cars will be even harder. Without incentives for car makers to produce those cars, and for motorists to buy them, it will not happen. But as seen in the rush for the 'cash for clunkers' bonus (as part of the economic stimulus of 2009 the German government paid car owners a $€ 2,500$ premium to exchange a car more than nine years old for a new one), such incentives can mobilize massive behavioural change. An effective green-car programme, backed by investment in the necessary infrastructure, would be an unmistakable signpost on the road to the post-fossil-fuel age — and not only in Germany. -

\section{Time for plan B}

\section{A court ruling to remove age limits on access to emergency contraception must prevail.}

$\mathrm{A}$ federal judge last week ordered the US Food and Drug Administration (FDA) to make the emergency contraceptive Plan B One-Step (levonorgestrel) available over-the-counter to all women and girls, irrespective of age. The ruling is a welcome one, and the administration of President Barack Obama would be wise to end its history of political interference in a scientific issue by declining to appeal the decision.

FDA officials have restricted access to the 'morning after' pill ever since the administration of George W. Bush, despite the consistent opinions of their scientists and advisers, who have been recommending universal over-the-counter access since 2003. The drug, a hormone used in many birth-control pills, has been widely shown to be safe and efficacious, and young teens have proven at least as adept as older women in following instructions for taking it. Nonetheless, the FDA continued to require girls younger than 17 to get a doctor's prescription, and women older than that to follow a burdensome proof-of-age procedure.

The drug regulator's reticence can be traced to pressure from conservatives, who argued - despite studies showing otherwise - that making Plan B easier to access would encourage promiscuity and sexual risk-taking in young teens. Abortion politics also had a role: although the pill is thought to act by preventing or delaying ovulation, it might also prevent implantation of a fertilized zygote.

In 2001, women's and reproductive-rights advocates petitioned the agency to remove the age restriction, without success. Their hope surged when a newly elected Obama publicly committed to letting agency scientists do their jobs, "listening to what they tell us, even when it's inconvenient - especially when it's inconvenient"

(see Nature 480, 413; 2011). Then, in December 2011, as FDA head Margaret Hamburg prepared to make the drug available without a prescription to girls younger than 17 , her boss overruled her. In her unprecedented action, Kathleen Sebelius, the US secretary of health and human services, speciously noted that $10 \%$ of 11 -year-old girls are capable of conceiving and implied that young girls could therefore be harmed by the drug. In fact, the only documented adverse effects are nausea and delayed menses, and an 11-year-old can buy a lethal dose of paracetamol for considerably less money and with no restrictions. All the same, Obama backed up Sebelius.

Now, Edward Korman, a senior judge in the eastern district of New York, has called Sebelius's action, which was taken less than a year before a closely contested presidential election, "politically motivated, scientifically unjustified, and contrary to agency precedent". In a scathing decision in a lawsuit against the FDA brought by women and reproductive-rights groups, Korman noted that Plan B One-Step would be one of the safest over-the-counter drugs. He added that the administration's position "is not about the potential misuse of Plan B by 11-year-olds ... [but] an excuse to deprive the overwhelming majority of women of their right to obtain contraceptives without unjustified and burdensome restrictions".

Those restrictions are particularly intrusive because time is of the essence in using the drug: the sooner after intercourse that the tablet is taken, the more likely it is to prevent pregnancy. The need to find an open pharmacy and show proof of age is not trivial, especially for poorer, younger and less-educated women - never mind asking those under 17 to get a doctor's prescription.

The judge's pointed ruling has given the Obama administration another chance to live up to the president's promise to respect agency scientists' findings "especially when it's inconvenient". But if

DNATURE.COM To comment online, click on Editorials at: go.nature.com/xhunqv the Department of Justice appeals, and prevails, then the ramifications will extend well beyond the fate of an emergency contraceptive. It will set a troubling precedent for political interference in drug-approval decisions. 